\title{
INTRODUKSI PEMANFAATAN ECENG GONDOK SEBAGAI PAKAN TERNAK FERMENTASI PADA PETERNAK KAMBING DESA WANADADI BANJAREGARA
}

\author{
Nuniek Ina Ratnaningtyas ${ }^{1}$, Bahrun Bahrun², Ratri Noor Hidayah ${ }^{3}$, Okti Herliana ${ }^{3 *}$ \\ ${ }^{1}$ Jurusan Ilmu Biologi, Fakultas Biologi, Universitas Jenderal Soedirman, Banyumas, Indonesia \\ ${ }^{2} J u r u s a n$ Ilmu Peternakan, Fakultas Peternakan, Universitas Jenderal Soedirman, Banyumas, Indonesia \\ ${ }^{3}$ Jurusan Agroteknologi, Fakultas Pertanian, Universitas jenderal Soedirman, Banyumas, Indonesia \\ *Penulis Korespodensi : o.herliana@gmail.com
}

\begin{abstract}
Abstrak
Desa Wanadadi terletak berbatasan langsung dengan Waduk Mrica. Dampak dari pembangunan waduk adalah terjadinya pergeseran sosial masyarakat dari yang semula mata pencahariannya petani menjadi buruh, dan beternak. Masalah utama yang dihadapi peternak adalah ketersediaan pakan, sedangkan yang dihadapi pengelola Waduk Mrica adalah sedimentasi dan pertumbuhan eceng gondok. Eceng gondok merupakan gulma air yang dapat mengganggu kualitas perairan. Penanggulangan eceng gondok merupakan salah satu upaya dalam manajemen sumber daya dan lingkungan perairan untuk menjaga kelestarian oraganisme parairan. Disisi yang lain tanaman ini memiliki beberapa manfaat dan potensi yang layak untuk dikembangkan, yaitu sebagai bahan pakan ternak karena kandungan proteinnya cukup tinggi, sehingga dapat digunakan sebagai pengganti pakan pabrikan untuk ternak ruminansia maupun unggas. Kegiatan ini bertujuan untuk memanfaatkan eceng gondok menjadi usaha konservasi perairan waduk dan memberikan nilai tambah di masyarakat, yaitu meningkatkan ketrampilan masyarakat dalam pembuatan pakan ternak fermentasi guna mendukung usaha peternakan kambing. Metode yang digunakan dalam kegiatan pemberdayaan masyarakat ini adalah PRA (Partisipatory Rural Appraisal) yaitu peran serta aktif seluruh masyarakat yang terlibat dalam kegiatan ini. Meliputi kegiatan: penyuluhan dan pelatihan pemanfataan eceng gondok sebagai bahan silase pakan kambing, Pembuatan Demplot percobaan ternak kambing, pendampingan dan evaluasi. Diharapkan kegiatan ini dapat memberikan manfaat bagi masyarakat Desa Wanadadi.
\end{abstract}

Kata Kunci: Budidaya Kambing; Eceng Gondok; Silase; Waduk Mrica.

\begin{abstract}
Wanadadi Village is located directly adjacent to the Mrica Reservoir. The impact of the reservoir building is a social shift from the people whose livelihoods were originally farmers to become laborers, and livestock. The main problem faced by farmers is the availability offeed, while what is faced by the manager of the Mrica Reservoir is sedimentation and growth of weeds. Eichhornia crasippes is a water weed that can interfere with water quality. Eichhornia crasippes prevention is one of the efforts in the management of resources and the aquatic environment to maintain the sustainability of wter microoganism. On the other hand this plant has several benefits and potential to be developed, namely as animal feed ingredients because the protein content is quite high, so it can be used as a substitute for manufacturing feed for ruminants and poultry. This activity aims to utilize water hyacinth into conservation efforts of reservoir waters and provide added value in the community, namely improving community skills in the manufacture offermented animal feed to support goat farming. The method used in this community empowerment activity is PRA (Partcipatory Rural Appraisal), namely the active participation of all communities involved in this activity. Includes activities: counseling and training on the use of water hyacinth as goat feed silage material, Making goat experimental demonstration plots, mentoring and evaluation. It is hoped that this activity can provide benefits for the people of Wanadadi Village
\end{abstract}

Keywords: Goat Livestock; Eichhornia Crasippe; Silase; Mrica Reservoir.

\section{PENDAHULUAN}

Desa Wanadadi merupakan salah satu desa yang terdampak pembangunan waduk Mrica, sebagian wilayah desa masuk ke area yang harus di aliri aliran sungai Serayu. Awalnya sebagian besar merupakan area pertanian. Keberadaan proyek PLTA dengan pembuatan bendungannya tentu memberikan dampak terhadap masyarakat. Perubahan pada lingkungan ekologis 
berpengaruh terhadap kehidupan sosial bagi yang langsung terkena ataupun yang berada disekitar proyek. Sebagian besar kaum tani pada daerah genangan waduk harus merelakan sawah dan tanah garapan yang selama ini menjadi tumpuan mata pencaharian. Semula perekonomian Desa Wanadadi ditopang oleh sektor pertanian berubah menjadi sektor perikanan, peternakan, buruh dan retribusi pasar/perdagangan. PT. Indonesia Power selaku pengelola operasional waduk Mrica melalui unit CSR (Coorporate Social Responsibility) terlibat dalam beberapa kegiatan pemberdayaan masyarakat khususnya pada desa-desa yang terdampak pembangunan waduk Mrica. Salah satunya adalah Desa Wanadadi. Sektor perikanan dan peternakan menjadi prioritas untuk dikembangkan mengingat lahan pertanian beralih fungsi menjadi bendungan.

Kegiatan peternakan di desa ini dilakukan secara mandiri dan berkelompok oleh beberapa orang yang menamakan diri Kelompok Menda Jaya. Anggota kelompok ternak ini berjumlah 7 orang dan diketuai oleh Bapak Suyitno, yang semua anggotanya merupakan pengelola sampah rumah tangga di Desa Wanadadi sehingga diharapkan dapat meningkatkan perekonomian mereka. Salah satu kendala yang dihadapi dalam usaha budidaya ternak adalah ketersediaan bahan pakan dan bagaimana meramu formulasi pakan yang kaya nutrisi dan hemat. Ketika musim kemarau, ketersediaan hijaun sumber pakan ternak kambing mengalami kelangkaan. Sehingga perlu dicarikan sumber pakan alternatif yang tersedia sepanjang musim.

Bagi pengelola Waduk Mrica masalah sedimentasi menjadi ancaman bagi keberlanjutan fungsi Waduk. Pada tahun 2011 sedimentasi waduk telah mencapai 92,01 juta m3 kubik, dengan laju sedimentasi 4,2 juta m3 per tahun. Tidak hanya sedimentasi yang menjadi masalah di Waduk Mrica, pertumbuhan enceng gondok (Eichhornia crassipes) yang menutupi hampir separuh permukaan juga menjadi ancaman (Suara Merdeka, 2 Februari 2011). Suatu upaya perlu diupayakan sehubungan dengan melimpahnya enceng gondok untuk menjaga kelestarian fungsi waduk. Enceng gondok termasuk tanaman air tawar liar dari famili Pontederiaceae yang menyebar hingga ke Amerika Selatan, secara alami tumbuh di daerah tropik dan subtropik. Perkembangan tanaman melalui biji dan anakan (El-Sayed, 2003). Masalah yang timbul dengan meluasnya enceng gondok antara lain adalah meningkatnya evapotranspirasi, penguapan dan hilangnya air melalui daunnya yang lebar, mengurangi penetrasi cahaya matahari yang berakibat menurunnya oksigen perairan lewat fotosintesis, mempercepat pendangkalan akibat tumbuhan yang mati dan turun ke dasar perairan, habitat bagi vektor penyakit pada manusia, mengganggu transportasi air dan keindahan perairan. Untuk mengatasi perkembangan eceng gondok yang dapat mengganggu debit air Waduk Mrica perlu dilakukan upaya pengendalian dan pemanfaatan eceng gondok agar mempunyai nilai tambah.
Penanggulangan eceng gondok di perairan merupakan salah satu usaha dalam manajemen sumber daya dan lingkungan perairan untuk menjaga kelestarian oraganisme parairan. Dalam dunia peternakan eceng gondok ini sebenarnya mempunyai manfaat yang besar karena kandungan proteinnya cukup tinggi sehingga memungkinkan digunakan sebagai pakan, pupuk maupun produksi biogas. Gunnarsson dan Petersen (2007) menyatakan, disebabkan tumbuh melimpah dan tingginya konsentrasi nutrien, enceng gondok digunakan sebagai pupuk umtuk tanah yang kekurangan nutrien sebagai pakan ternak. Lu et al. (2008) mencoba enceng gondok sebagai pakan itik, didapatkan berat telur $2.36 \%$ lebih tinggi dari pada kontrol Sehingga dapat digunakan sebagai pakan alternatif pengganti pakan pabrik untuk ternak ruminansia maupun unggas. Eceng gondok harus difermentasi terlebih dahulu karena kandungan seratnya sangat tinggi. Proses Fermentasi Mampu meningkatkan kandungan nutrient eceng gondok yaitu Protein sebesar 10-14\%, serat 32-47\% dan kadar abu $12 \%$. Dan mampu meningkatkan secara significant bobot sapi sebesar $10 \%$ dari pakan hijaun segar tanpa fermentasi selama kurun waktu pemeliharaan 3 bulan (Bahrun, 2010).

Kegiatan pemberdayaan masyarakat desa Wanadadi untuk memanfaatkan eceng gondok sebagai bahan pakan ternak dan diharapkan mampu mengatasi masalah penurunan kualitas perairan sekaligus memberikan introduksi teknologi pemanfaatan eceng gondok dibidang peternakan dan pertanian sehingga mampu memberikan nilai tambah dan meningkatkan kesejahteraan masyarakat Desa Wanadadi. Untuk itu tim pengabdian dari Universitas Jenderal Soedirman tertarik untuk menggali potensi eceng gondok sebagai bahan pakan ternak. Ada 2 solusi permasalahan sekaligus yang dapat dipecahkan, yaitu penurunan kualitas perairan waduk mrica dan ketersediaan bahan pakan bagi kelompok peternak di Desa Wanadadi.

\section{BAHAN DAN METODE}

Pengabdian Kepada Masyarakat (PPM) ini dilaksanakan di Desa Wanadadi Kabupaten Banjarnegara Merupakan skim pengabdian berbasis riset kerjasama antara tim pelaksana dari Universitas Jenderal Soedirman dengan PT. Indonesia Power. Khalayak sasaran adalah kelompok peternak Mendajaya. Bahan dan alat yang digunakan dalam kegiatan ini adalah: materi penyuluhan mengenai budidaya kambing, materi penyuluhan mengenahi pengolahan silase dar, eceng gondok, molase, pakan hijauan, bambu, kayu untuk pembuatan kandang, bibit ternak kambing jawa randu dan sapera

Metode yang digunakan dalam kegiatan ini adalah PRA (Partisipatory Rural Appraisal) yaitu peran serta aktif seluruh masyarakat yang terlibat dalam kegiatan ini. Berikut ini adalah metode dan tahapan pelaksanaan kegiatan. 
Tabel 1. Metode Pelaksanaan Program.

\begin{tabular}{cll}
\hline No & \multicolumn{1}{c|}{ Kegiatan Program } & \multicolumn{1}{c}{ Metode } \\
1 & $\begin{array}{l}\text { Penyuluhan Budidaya } \\
\text { Kambing (Jawa Randu } \\
\text { dan Sapera) }\end{array}$ & $\begin{array}{l}\text { Penyuluhan, } \\
\text { pelatihan dan } \\
\text { diskusi }\end{array}$ \\
\hline & $\begin{array}{l}\text { Penyuluhan dan } \\
\text { pelatihan pembuatan } \\
\text { pakan fermentasi/silase } \\
\text { eceng gondok }\end{array}$ & $\begin{array}{l}\text { Penyuluhan, } \\
\text { pelatihan dan } \\
\text { diskusi }\end{array}$ \\
\hline 3 & $\begin{array}{l}\text { Pembuatan Kandang } \\
\text { /Demplot Budidaya } \\
\text { Kambing }\end{array}$ & $\begin{array}{l}\text { Penyuluhan, } \\
\text { praktek dan diskusi }\end{array}$ \\
\hline 4 & Pengadaan Bibit ternak & Praktek dan diskusi \\
\hline & $\begin{array}{l}\text { Aplikasi pemberian } \\
\text { pakan silase eceng } \\
\text { gondok terhadap hewan } \\
\text { ternak }\end{array}$ & $\begin{array}{l}\text { Pelatihan, praktek } \\
\text { dan diskusi }\end{array}$ \\
\hline 6 & & $\begin{array}{l}\text { Pelaksanaan pree } \\
\text { test, post test dan } \\
\text { diskusi }\end{array}$ \\
\hline
\end{tabular}

Untuk menjamin keberlanjutan usaha ternak kambing dari kelompok Mendajaya ini maka dibutuhkan SOP untuk dilaksanakan bersama seluruh anggotadan optimalisasi manajemen usaha dan peningkatan komunikasi proaktif dengan pemerintahan desa maupun SKPD teknis di tingkat kecamatan (Dinas Peterikan dan Perinkop) kemudia di akhir kegiatan dilakukan evaluasi untuk mengetahui apakah kegiatan dapat bejalan dengan baik.

\section{HASIL DAN PEMBAHASAN}

Kegiatan pengabdian masyarakat ini merupakan kerjasama antara akademisi dari Universitas Jenderal Soedirman dan PT. Indonesia Power selaku pengelola operasional waduk Mrica. PT Indonesia Power melalui unit CSR (Coorporate Social Responsibility). Program CSR ini selain sebagai pengejawantahan kepatuhan korporasi pada perangkat hukum yang terkait UndangUndang No. 40 Tahun 2007 tentang Perseroan Terbatas (UUPT) serta Peraturan Pemerintah No. 47 Tahun 2012 tentang Tanggung Jawab Sosial dan Lingkungan (TJSL) Perseroan Terbatas (PP 47/2012) juga menjadi penguatan eksistensi korporasi dalam pemberdayaan Masyarakat yang berkontribusi kepada peningkatan kesejahteraan perekonomian masyarakat di Desa Wanadadi. Di sisi lain dengan adanya kegiatan pemberdayaan masyarakat dengan obyek eceng gondok sebagai bahan pakan ternak, maka diharapkan akan sedikit banyak mengurangi permasalahan penurunan kualitas perairan waduk dikarenakan perkembangbiakan eceng gondok. Rangkaian kegiatan pengabdian masyarakat ini yaitu:

\subsection{Kegiatan FGD (Forum Group Discussion) Mengenai Budidaya Kambing Perah}

Kegiatan Sosialisasi dan Forum Group Discusion mengenai budidaya kambing perah ini dilaksanakan pada tanggal 12 Juli 2018 bertempat di Balaidesa
Wanadadi dengan audiens adalah kelompok Peternak Mendajaya, perwakilan masing-masing RT, perangkat Desa dan narasumber adalah salah satu anggota tim pengabdian, Ir. Bahrun MP dari Fakultas Peternakan Unsoed dan Bpk. Ir. Junarto dari Dinas Peternakan Banjarnegara. Kegiatan ini bertujuan untuk memberikan pengetahuan dan berbagi pengalaman seputar budidaya kambing. Materi yang diberikan adalah pengenalan berbagai jenis kambing, sumber pakan kambing, penyakit-penyakit yang sering diderita oleh kambing, perawatan harian dan kebersihan kandang. Audiens yang hadir antusias dengan materi yang diberkan dan mendapatkan tambahan pengetahuan sehingga diharapkan makin terampil dalam usaha budidaya kambingnya, dokumentasi kegiatan tercantum dalam gambar 1 .
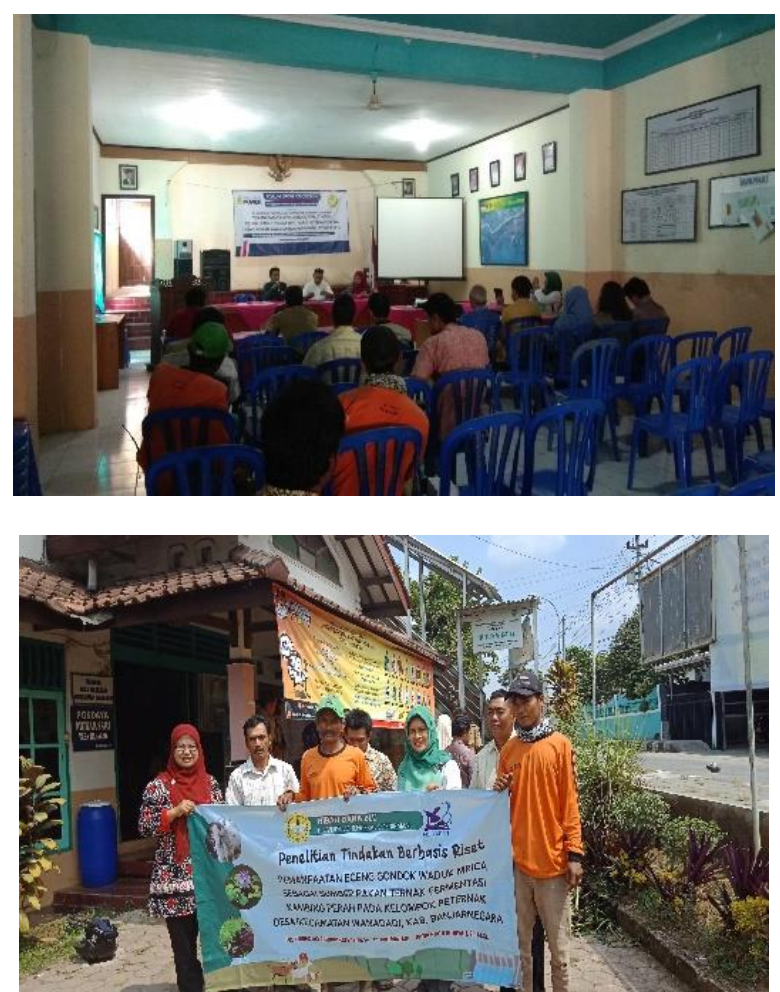

Gambar 1. Kegiatan FGD dan sosialisasi budidaya kambing.

\subsection{Pelatihan Pembuatan Pakan Fermentasi Dari Eceng Gondok}

Kegiatan pelatihan dan praktek pembuatan silase berbahan eceng gondok dilaksanakan pada tanggal 31 Juli 2018 bertempat di Balidesa Wanadadi. Pada awalnya kelompok ternak Mendajaya hanya memberi pakan hijaun dan rumput saja pada kambing peliharaannya, akan tetapi apabila memasuki musim kemarau ketika rumput dan hijaun susah didapatkan karena sebagian besar lahan pertanian mengalami kekeringan maka hal ini menjadi satu kendala dalam usaha mereka. Introduksi pembuatan pakan fermentasi dari eceng gondok diharapkan bisa menjadi solusi agar pakan dengan kandungan nutrisi yang baik mendukung pertumbuhan kambing dapat tersedia sepanjang musim. Pemanfaatan enceng gondok untuk pakan ternak harus difermentasi terlebih dahulu karena kandungan seratnya 
sangat tinggi. Proses Fermentasi Mampu meningkatkan kandungan nutrient eceng gondok yaitu Protein sebesar $10-14 \%$, serat $32-47 \%$ dan kadar abu $12 \%$. Dan mampu meningkatkan secara significant bobot sapi sebesar $10 \%$ dari pakan hijaun segar tanpa fermentasi selama kurun waktu pemeliharaan 3 bulan (Bahrun, 2010). Anggota kelompok Mendajaya sangat antusias terhadap kegiatan Introduksi pengolahan eceng gondok menjadi silase.

Berikut ini tahapan pembuatan silase: Pertama tama, enceng gondok ditiriskan sekurang kurangnya sehari semalam, sebelum kemudian dicacah. Selanjutnya dilakukan pencampuran dengan komposisi dua enceng gondok dengan satu konsentrat. Dengan perbandingan $2: 1$, jika enceng gondoknya $100 \mathrm{~kg}$, konsentratnya 50 kilogram. Konsentrat ini memiliki kandungan protein sekurang kurangnya 13 persen. Selain itu juga ditambah tetes tebu sekitar $1-2$ persen, Campuran tersebut kemudian diperam sekurang kurangnya 2 minggu dalam wadah kedap udara seperti drum, atau kantung plastik dengan tingkat kepadatan 600 kilogram per meter kubik, Setelah itu, pakan dari olahan enceng gondok pun siap digunakan. Hasil percobaan yang dilakukan pada penggemukan domba tahun 2013 dan sapi potong pada tahun 2014, didapatkan pertambahan bobot badan pada sapi dan domba sangat baik, yakni 90-110 gram per hari pada domba dan 0,8 - 1,3 kilogram per hari pada sapi potong, Berikut ini adalah gambar pelatihan pembuatan silase:
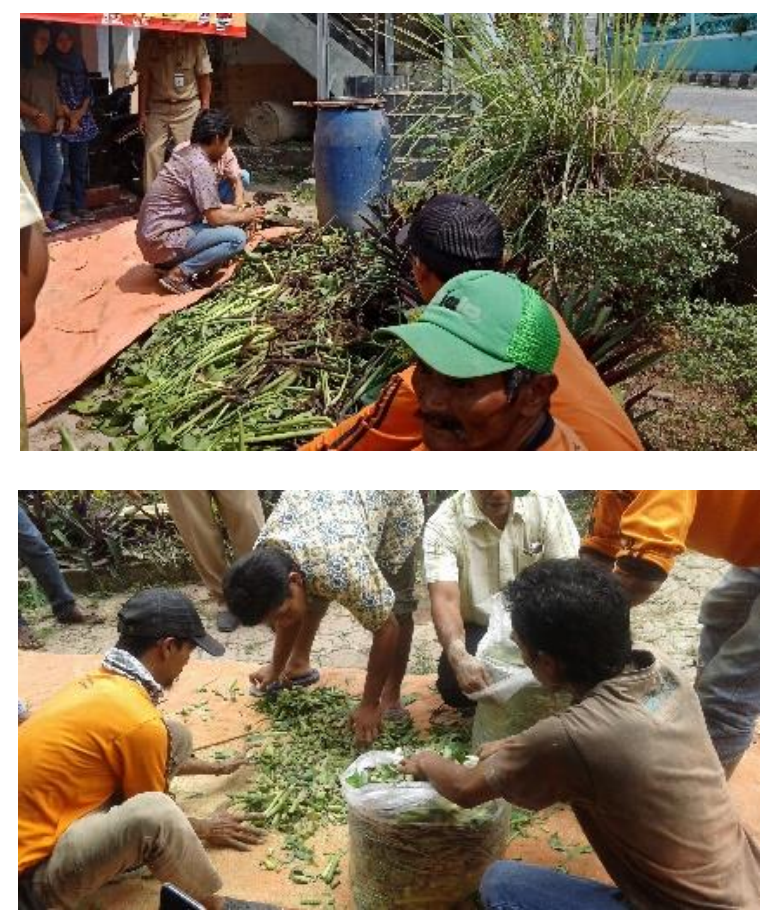

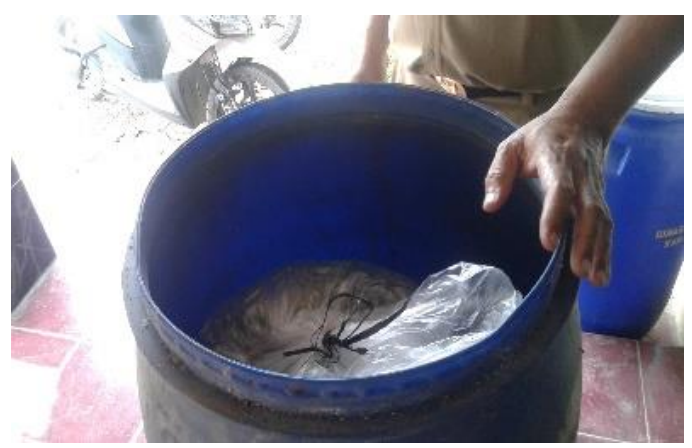

Gambar 2. Pelatihan dan praktek pembuatan silase eceng gondok.

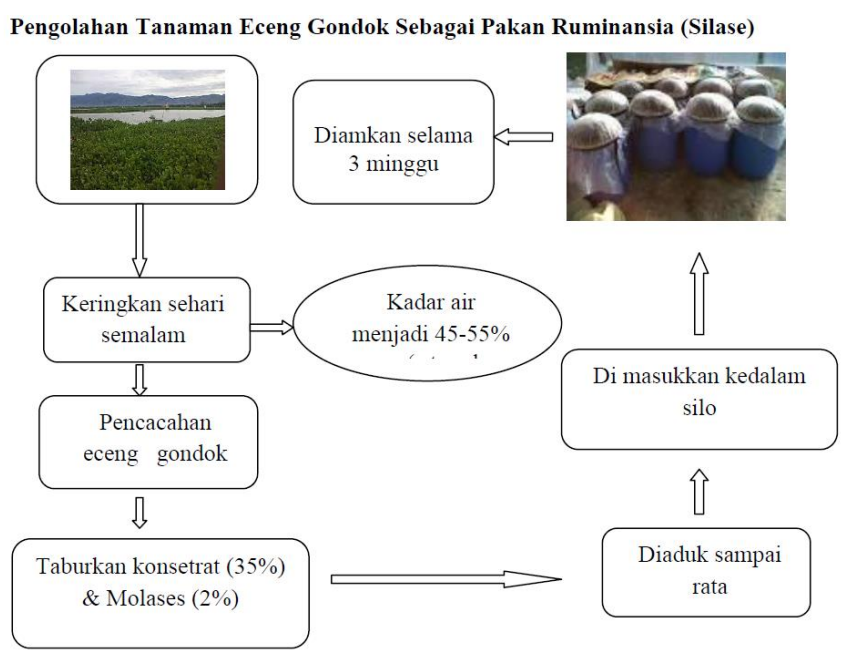

Gambar 3. SOP pembuatan silase eceng gondok.

\subsection{Pembuatan Kandang Dan Pengadaan Bibit Ternak Kambing}

Kandang Kambing berfungsi sebagai tempat kelangsungan hidup Kambing, Kandang juga menentukan tingkat keberhasilan dalam melindungi dari serangan pemangsa, cuaca serta menjadi pemicu agar ternak tetap sehat. Kambing jenis apapun pada dasarnya sama yaitu membutuhkan kandang yang nyaman untuk berkelangsungan hidup.

Tujuan Dan Fungsi Pembuatan Kandang Kambing yaitu:

a) Melindungi Kambing dari sesuatu yang membahayakan kesehatan dan keselamatannya, serangan hewan pemangsa dan cuaca.

b) Membuat Kambing merasa nyaman dengan dapat melakukan aktifitas tanpa hambatan seperti makan, minum, tidur, dll.

c) Mempermudah dalam mengawasikondisi Kambing karena berada dalam suatu tempat.

Pembangunan kandang kambing pada kegiatan ini disesuaikan dengan populasi yang dihibahkan. Karena kegiatan dilaksanakan bersama oleh 1 kelompok maka dibuat kandang komunal dengan kapasitas 12 ekor, terdiri dari 8 kambing jawa randu ( 1 jantan 7 betina) dan 4 ekor kambing sapera (1 jantan 3 betina) lokasi kandang berada agak jauh pemukiman penduduk. Kandang dibuat permanen dengan ukuran 15x2 m 
dengan sistem panggung dan beratap genting diharapkan agar masa pakainya lama. Setelah kandang siap digunakan maka bibit ternak siap untuk dikirim dan ditempatkan pada kandang baru. Umur bibit kambing berkisar 1,5 sampai dengan 2 tahun. Usia tersebut merupakan masa yang baik bagi proses reproduksi kambing.

Ada beberapa kriteria yang harus diperhatikan dalam memilih bibit ternak agar benar-benar dapat tumbuh dan berkembangbiak dengan baik. Kriteriannya antara lain:

1) Mata (pilih mata yang bening, mata bersinar cerah, tajam, bukan yang kemerahan)

2) Mulut (pilih yang bersih dan tidak berlendir)

3) Tulang belakang (bentuk yang lurus, tidak melengkung ke bawah)

4) Wilayah dada (bentuknya agak menonjol)

5) Ekor (bentuk yang melebar, bukan yang berbentuk seperti cambuk) serta bulunya halus dan mengilap.

Bibit ternak di beli pada kelompok peternak yang sudah lama menjalankan usahannya yaitu Kelompok Ternak Sido Makmur Desa Penican Kabupaten Purbalingga. Ternak dipilih yang memenuhi kriteria sehat dan produktif. Berikut ini gambar kandang kambing dan proses pengiriman ternak untuk pelaksanaan demplot budidaya kambing jawa randu dan perah.
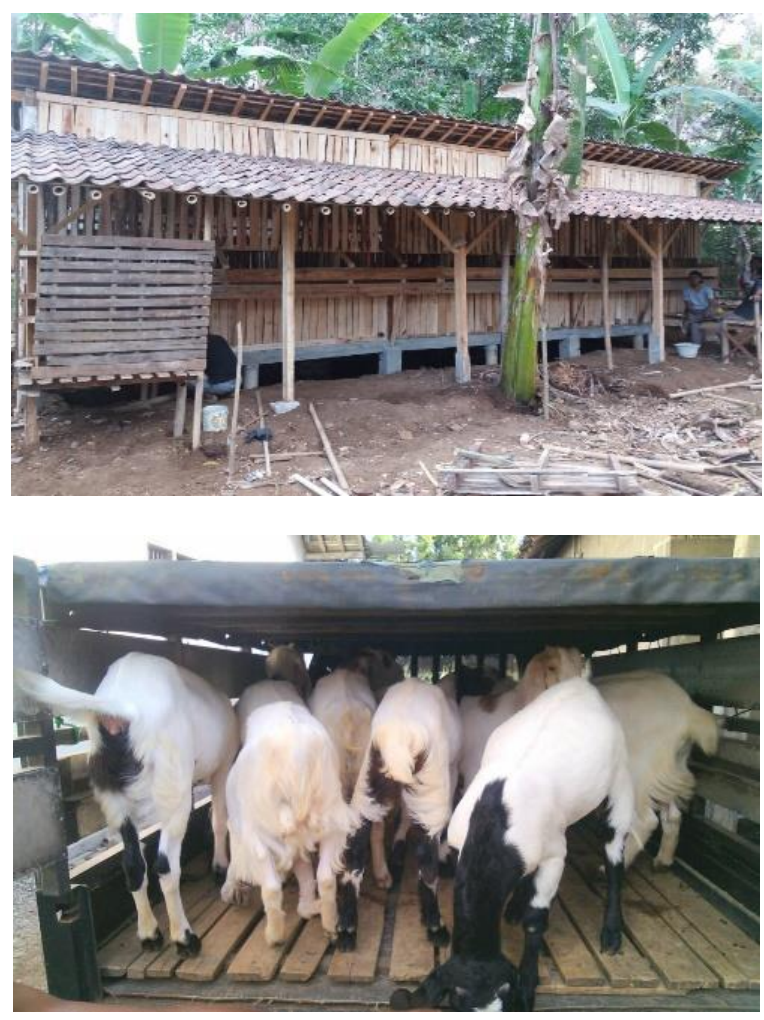

Gambar 4. Kandang Kambing Dan Bibit Ternak Sebagai Demplot.

\subsection{Pendampingan pemeliharaan dan Evaluasi Kegiatan}

Kegiatan pemeliharaan kambing perlu mendapat pendampingan yang intensif agar peternak merasa kegiatannya mendapat dukungan dan jika menemukan kendala dilapangan misalnya ternak sakit atau masuk fase reproduksi dapat segera mengatasi kondisi tersebut. Dari 7 ekor kambing jawa randu betina setelah 3 bulan mulai bunting dan kambing betina sapera juga mengalami pertaambahan bobot. Evaluasi terhadap pelaksanaan program pengabdian ini dilihat dari segi fisik serta non fisik. Kegiatan evaluasi dilakukan oleh tim pelaksana dalam rangka mengukur perubahan pengetahuan, ketrampilan dan perilaku khalayak sasaran. Hasil fisik dievaluasi berdasarkan pemantauan sikap dan aktivitas peserta selama mengikuti ceramah serta praktek pengolahan pakan. Hasil evaluasi menunjukkan bahwa penyelenggaraan penyuluhan yang dilakukan dalam bentuk ceramah, diskusi, yang didukung dengan praktek pengolahan pakan, telah mampu meningkatkan pengetahuan peserta. Hal ini dapat dilihat dari adanya peningkatan pemahaman dan keterampilan peserta dalam mengenali dan memilih bahan untuk pengolahan pakan. Dengan demikian dapat dikatakan bahwa materi penyuluhan dapat diterima dan dipahami oleh peserta.

Faktor pendorong yang menunjang keberhasilan pelaksanaan program pengabdian ini antara lain adalah adanya kerjasama yang baik antara tim pengabdi, PT. Indonesia Power, khalayak sasaran serta per. Faktor penghambangkat desa setempat. Kendala dalam menerapkan alih teknologi ini adalah cuaca, yang sering mendung dan turun hujan, sehingga kegiatan kadang sering terhambat dan harus dijadwal ulang. Secara keseluruhan pelaksanaan kegiatan pengabdian kepada masyarakat ini telah dapat terlaksana dengan baik dengan indicator sebagai berikut:

Tabel 2. Indikator Keberhasilan Pelaksanaan Program Pemberdayaan.

\begin{tabular}{|c|c|c|c|}
\hline No & Program & $\begin{array}{l}\text { Sebelum } \\
\text { kegiatan }\end{array}$ & Setelah \\
\hline 1 & $\begin{array}{c}\text { Penyuluhan } \\
\text { Budidaya } \\
\text { Kambing } \\
\text { (Jawa Randu } \\
\text { dan Sapera) }\end{array}$ & $\begin{array}{l}\text { Kegiatan ternak } \\
\text { kambing } \\
\text { dilaksanakan } \\
\text { sebagai usaha } \\
\text { sampingan } \\
\end{array}$ & $\begin{array}{c}\text { Kegiatan } \\
\text { ternak } \\
\text { kambing } \\
\text { mulai serius } \\
\text { ditekuni dan }\end{array}$ \\
\hline 2 & $\begin{array}{l}\text { Penyuluhan } \\
\text { dan } \\
\text { pelatihan } \\
\text { pembuatan } \\
\text { pakan } \\
\text { fermentasi/si } \\
\text { lase eceng } \\
\text { gondok }\end{array}$ & $\begin{array}{l}\text { Pakan ternak } \\
\text { adalah rumput } \\
\text { dan hijauan }\end{array}$ & $\begin{array}{c}\text { Peternak } \\
\text { mulai dapat } \\
\text { meramu silase } \\
\text { dari bahan } \\
\text { eceng gondok }\end{array}$ \\
\hline 3 & $\begin{array}{l}\text { Pembuatan } \\
\text { Kandang } \\
\text { /Demplot } \\
\text { Budidaya } \\
\text { Kambing } \\
\end{array}$ & $\begin{array}{l}\text { Kandang ternak } \\
\text { sederhana dan } \\
\text { kurang terjamin } \\
\text { kebersihannya }\end{array}$ & $\begin{array}{c}\text { Kandang lebih } \\
\text { permanen dan } \\
\text { terjaga } \\
\text { kebersihannya }\end{array}$ \\
\hline 4 & $\begin{array}{l}\text { Pengadaan } \\
\text { Bibit ternak }\end{array}$ & $\begin{array}{c}\text { Masing-masing } \\
\text { peternak hanya } \\
\text { punya } 1-2 \text { ekor } \\
\text { dipelihara } \\
\text { secara pribadi } \\
\text { di rumah }\end{array}$ & $\begin{array}{c}\text { Penambahan } \\
\text { bibit ternak } \\
\text { sejumlah } 12 \\
\text { ekor untuk } \\
\text { dipelihara } \\
\text { bersama dan } \\
\text { terus di pantau } \\
\text { perkembangan } \\
\text { nya }\end{array}$ \\
\hline
\end{tabular}




\begin{tabular}{|c|c|c|c|}
\hline \multirow{5}{*}{5} & $\begin{array}{c}\text { Aplikasi } \\
\text { pemberian } \\
\text { pakan silase } \\
\text { eceng } \\
\text { gondok } \\
\text { terhadap } \\
\text { hewan } \\
\text { ternak }\end{array}$ & $\begin{array}{c}\text { Pada musim } \\
\text { kemarau } \\
\text { peternak susah } \\
\text { mendapatkan } \\
\text { hijaun dan } \\
\text { rumput segar }\end{array}$ & $\begin{array}{c}\text { Pada Musim } \\
\text { kemarau } \\
\text { peternak } \\
\text { mensubtitusi } \\
\text { pakan dengan } \\
\text { silase eceng } \\
\text { gondok }\end{array}$ \\
\hline \multirow{6}{*}{6} & $\begin{array}{c}\text { Evaluasi } \\
\text { kegiatan }\end{array}$ & $\begin{array}{c}\text { Pengetahuan } \\
\text { dan ketrampilan } \\
\text { terbatas }\end{array}$ & $\begin{array}{c}\text { ketrampilan } \\
\text { peternak } \\
\text { meningkat } \\
\text { diharapkan }\end{array}$ \\
& & & $\begin{array}{c}\text { kesejahteraan } \\
\text { meningkat }\end{array}$ \\
& & &
\end{tabular}
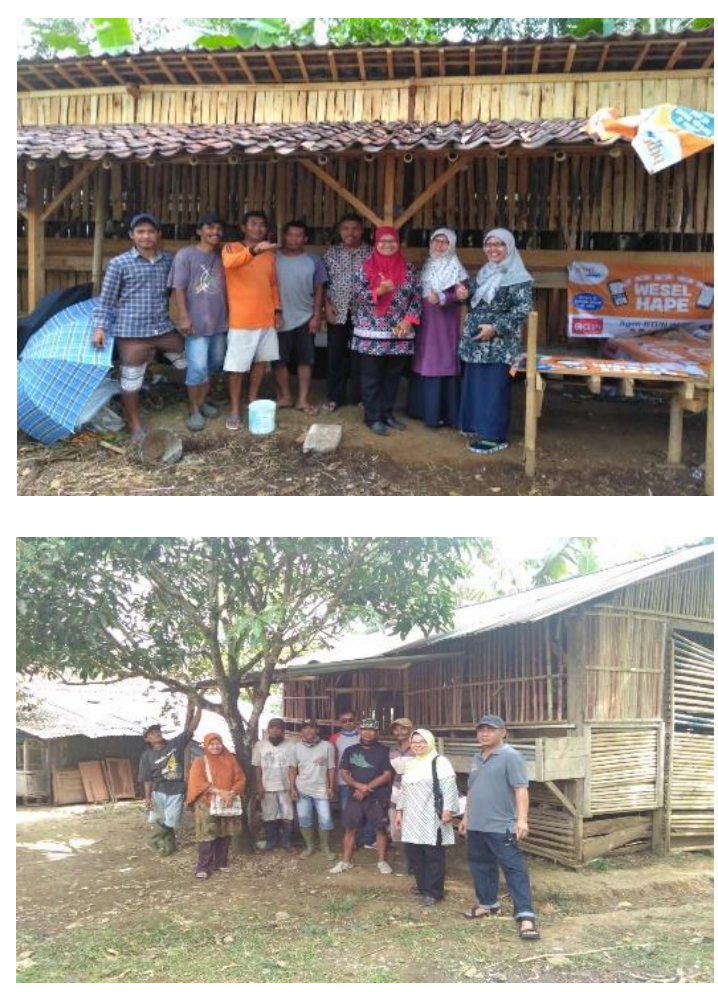

Gambar 5. Kegiatan Monitoring Dari Pelaksana Kegiatan Secara Berkala.

\section{KESIMPULAN}

1. Kegiatan pemberdayaan masyarakat guna memanfaatkan eceng gondok sebagai pakan fermentasi/silase pada kambing di Desa Wandadi Kabupaten Banjarnegara telah terlaksana dengan baik dan lancar. Anggota kelompok dapat terlibat secara aktif dengan seluruh acara yang diselenggarakan.

2. Khalayak sasaran meningkat pengetahuan dan keterampilannya dalam memanfaatkan dan mengolah eceng gondok menjadi pakan fermentasi/silase

3. Pakan hasil olahan telah berhasil diaplikasikan untuk pemeliharaan kambing dengan menghasilkan pertumbuhan yang baik, sehingga dapat mengurangi ketergantungan terhadap pakan hijauan dan rumput yang langka saat musim kemarau
4. Kambing yang dihibahkan mengalami perkembangbiakan, 4 ekor kambing betina jawa randu dan 2 ekor sapera sedang bunting

\section{UCAPAN TERIMA KASIH}

Penulis mengucapkan terimakasih kepada LPPM Universitas Jenderal Soedirman atas pendanaan kegiatan Pengabdian Masyarakat Skim Berbasis Riset dengan No. Kontrak 2656/UN23/14/PN/2018 dan CSR PT. Indoensia Power atas kontribusi sharing pendanaan, mahasiswa yang telah membantu kegiatan ini dilapangan (Bagas, Oryza dan Sandra) dan Kepala desa Wanadadi Bpk Sigit Utoyo sehingga kegiatan ini dapat dilaksanakan dengan baik

\section{DAFTAR PUSTAKA}

Bahrun, 2010, Imbangan Eceng Gondok Dengan Rumput Lapang sebagai Pakan Hijauan Sapi Perah ditinjau dari Kecernaan Bahan Kering dan Bahan Organic Secara in In vitro. Laporan Hasil Penelitian Dosen Pemula. LPPM Unsoed.

El-Sayed, A. F. M., 2003. Effects of fermentation methods on the nutritive value of water hyacinth for Nile tilapia (Oreochromis niloticus (L.) fingerlings. Aquaculture, 218: 471-478

Gunnarsson, C.C. and C.M. Petersen. 2007. Water Hyacinths as a Resource in Agriculture andEnergy Production: a Literature Review. Waste Manag. 27(1):117-129 